\title{
Proceeding
}

Supplementary Issue: Summer Conferences of Sports Science. Costa Blanca Sports Science Events, 20-21 September 2019.

Alicante, Spain.

\section{Between analogue past and digital present, The Sports Almanac: A didactic proposal for the History of Sport}

\author{
DIEGO DAVIDE ${ }^{1}$, ROBERTA ROSA ${ }^{2}$, DOMENICO TAFURI ${ }^{1}$ \\ ${ }^{1}$ Parthenope University, Naples, Italy \\ 2IUL Telematic University, Italy
}

\begin{abstract}
Laboratory didactic activity with the active involvement of students, no longer seen as passive recipients of a top-down knowledge but as active protagonists of the training moment and the opportunities offered by the digital world, are the starting point of this didactic experience aimed at creating a photographic almanac, in which the sports performance or event is analyzed in the light of a larger and more complex picture of historical events. Thus the student is encouraged to experiment with a new narrative mode, use a new source, read critically and learn no longer according to a sterile memorization, but by developing specific skills. Keywords: Sport; History of sport; Digital humanities; Digital teaching.

\section{Cite this article as:}

Davide, D., Rosa, R., \& Tafuri, D. (2019). Between analogue past and digital present, The Sports Almanac: A didactic proposal for the History of Sport. Journal of Human Sport and Exercise, 14(5proc), S1944-S1949. doi:https://doi.org/10.14198/hhse.2019.14.Proc5.14
\end{abstract}

Corresponding author. Parthenope University, Naples, Italy.

E-mail: domenico.tafuri@uniparthenope.it

Supplementary Issue: Summer Conferences of Sports Science. Costa Blanca Sports Science Events, 20-21 September 2019. Alicante, Spain.

JOURNAL OF HUMAN SPORT \& EXERCISE ISSN 1988-5202

(c) Faculty of Education. University of Alicante

doi:10.14198/jhse.2019.14.Proc5.14 


\section{INTRODUCTION}

Excluded from high school final exams, mortified by the school curricula, neglected by the students who consider it a discipline devoid of practical value, History today goes through a moment of "crisis" about which scholars have long wondered. If possible, a much more difficult condition is experienced by that particular branch of the discipline which has placed the world of Sport and, more generally, sports culture and its economic, political and social repercussions at the centre of its research activity. In fact, if in the Nineties the History of Sport achieved important goals with the creation of specialized research centres, workshop activities and the launch, at the University of Teramo, of a European Master on Sport, with the ISEF (the Italian College of Physical Education) turning into Faculty, this growth process has undergone a sharp stop 1. In the new-born faculties of Motor Sciences, in fact, the humanities were forced to give way to the medical area disciplines. However, the reform was not the only reason of the decline in historical sports studies in Italy. They are also hampered by the endemic lack of sports archives, both at public and private bodies and organizations level. Therefore, if the documentary heritage accessible to scholars is scarce, a good part of it (perhaps the most relevant) is still submerged and at risk of dispersion².

Waiting for a change of direction, which brings the History of Sport back to its proper place, one of the possible strategies to be implemented in order to try to subtract Clio's discipline from the marginalization it seems destined for, in everyday didactic practice, is that of the laboratory or "product" didactics, to be carried out in a transversal way and involving (where possible) also other courses in the curriculum of the degree courses in Motor Science.

In this perspective, "the Sports Almanac" was a didactic experiment that provided for the active involvement of the participants, who had the task of researching, cataloguing and archiving the sources and using multimedia channels to support traditional didactics. The goal was the recovery of the photographic documentation that marked particular moments of the sports history, not only of our country; an additional goal, following a critical analysis aimed at placing the individual images in a composite universe of events, was the creation of an Almanac, under the form of short videos made by each participant. A path allowing the student taking in the creative moment of the story of the past, and grasping the epistemological foundations of the discipline, was thus developed.

\section{COURSE STRUCTURING}

Telematic universities, e-learning platforms, blogs created by teachers and students for the exchange of communications and didactic materials, are now part of everyday life in the world of secondary and university education. "Traditional" academic institutions themselves, far from disdaining this new modality, have set up special structures for the management of online content and "official" pages opened on the main social networks. Of equal importance are the publishing houses, which, in a cost-reduction perspective, have begun to transfer a part of the contents from paper manuals to websites with access reserved for book buyers.

On the basis of these examples, and in order to test the didactic possibilities offered by the breaking of the digital world in the field of human sciences, the workshop activity that will be introduced in these pages provided for the creation of a virtual classroom dedicated to the in-depth study of the topics covered by the

\footnotetext{
1 Law Decree n. 178 dated May 8, 1998.

2 N. Santarelli, A. Teja, Chi ha ucciso la storia dell'educazione fisica e dello sport in Italia? in Sport and Violence, Universisad Pablo de Olavide, Cadiz, 2006, pp. 234-240.
} 
lectures, in a sort of continuous training able to keep the teacher-learner dialogue open even beyond the single weekly meeting established by the academic calendar.

A group was created on the Facebook social network, within which the teaching staff played the role of moderator, constantly urging a critical analysis of the sources and guaranteeing the scientific nature of the contents shared by the students, who often showed confused knowledge and chronologically disordered.

In fact, very often, it happens that the new generations come into contact for the first time with the events of History through the narrative supporting movies, TV series or specially designed television formats ${ }^{3}$. This "encounter", while generating a certain degree of knowledge of the past and of the particular historical conjuncture linked to a particular event (also a sports-type one), does not provide the right chronological position and omits the causal logical relationships for the benefit of a story telling that nods to the audience of users.

Two examples are enough to explain it all. If we showed to the members of the millennial generation the now iconic image of Mohamed Ali knocking out Foreman during the match in Kinshasa, most of them would be able to recognize the sportsmen, but certainly few of them would be able to place the sports event in the socio-cultural environment of those years. The same can be said for Diego Maradona's picture who, during the Mexico 1986 semi-final, played by Argentina and England, threw the ball into the opponent's goal by touching it with his fist. Everyone can recognize that image, the "mano de dios", but very few are able to decline the rivalry between England and Argentina outside the sports arena, making it date back to the clash for the Falkland/ Malvinas islands.

Specifically, as for the completed workshop path, this was aimed at the realization of a sports almanac by using the photograph as a starting document, examined in its three possible functions: a source of history source and agent, and a means to tell the history ${ }^{4}$.

When introducing the topic of photography as a history agent, emphasis was placed on what is perhaps its main characteristic, namely its extraordinary evocative power. As widely demonstrated, in fact, it has the ability "to influence collective behaviours, build and consolidate group identities, influence political choices, and finally build memory"5.

To allow students using photography as a source and document it is necessary to enable them to decrypt its language, so that the image can be translated into written form. To this end, we have tried to illustrate the technical aspects of image production, from optics to mechanics, development and printing, to then underline the way in which, when placed on the work bench of the historian, it must be appropriately questioned in order to reveal its contents, dissolving the ambiguities and making the omissions resurface.

In this regard, a useful didactic and communicative strategy seemed that of using the famous photograph depicting the passage of the "water bottle" between the cyclists Coppi and Bartali, taken on the Galibier pass by the Omega Fotocronache photographer, Carlo Martini. In the shot we can see the two eternal rivals passing each other a bottle during a difficult climb. On the image, which has become the symbol of healthy sports rivalry and fair play, there is much to say. In the first place, none of the two cyclists has ever revealed

\footnotetext{
${ }^{3}$ An example may be the format conducted by Federico Buffa and broadcast on the Sky channel, "Federico Buffa racconta".

${ }^{4}$ G. D'Autilia, L'indizio e la prova. La storia nella fotografia, Milan, la Nuova Italia Editor, 2001.

5 Therein, p. 115.
} 
who was passing the "bottle" to, but above all, many doubts have been advanced on its authenticity. Vito Liverani, sports photographer and owner of the Omega Fotocronache agency, as well as the "enciclopedia" journalist Gianpaolo Ormezzano, talked about a fake post eventum, i.e. a "previously-planned" photograph, because the scene was reconstructed and crystallized in the photographic image after that situation actually happened ${ }^{6}$. This is an aspect that, from a historical point of view, cannot be reduced to mere curiosity for the fans of the sector. The document, in fact, enriches the already conspicuous number of contemporary photographic fakes, elaborated with different purposes by publishers but also by government bodies ${ }^{7}$. A critical analysis of some iconic images was then carried out, useful to convey the reflection on the connection strategies between image and historical nodes. John Dominis's photo entitled Black power Salute, taken at the Mexico City Olympics, served to introduce the theme of the 'Sixty-Eight', later developed by some students in their final work; the image of the Ethiopian marathon runner Abebe Bikila who, by running barefoot, managed to win the specialty race during the Rome Olympics, was the occasion for a study on European colonialism in Africa ${ }^{8}$.

\section{RESEARCH METHODOLOGY AND TOPICS}

After providing the participants with some basic survey tools, the operational phase of the project was launched, which involved the active participation of the students who were asked to go to the Tucci Book Store in Naples and to the periodicals section of the National Library of Naples, in order to proceed with the counting of the main sports magazines but also of the local, national and international newspapers; all this in order to search for images that could be linked to particular historical nodes. As an alternative, they were also give the possibility to draw on their family album, with photographs relating to sports activities carried out even at an amateur level by the members of the photo, or linked to particularly felt moments of sport, as the celebrations for the victory of the championship of their favourite football team, the victory of a world championship by Italian teams and, more generally, images of sports events. For each of these photographs, they were asked to fill in a cataloguing card aimed at collecting some basic information.

\begin{tabular}{l}
\hline Photo cataloguing card \\
\hline Place of finding \\
Publication type \\
Year of publication \\
Shooting opportunity and year \\
State of preservation \\
Purpose or function \\
Direct information \\
Indirect information \\
Knowledge integration
\end{tabular}

The images chosen, where necessary, were digitally transformed through a scanning process and then uploaded onto a dedicated internet page, so that a virtual archive shared by the educational community on

\footnotetext{
${ }^{6}$ For a discussion on the history of sports rivalry between the two Italian cyclists, we recommend reading "Coppi e Bartali". Una storia italiana raccontata ai miei figli by Ennio Doris and Pier Augusto Stagi, Milan, Solferino Editor, 2019.

7 P.Preto, I falsi fotografici nella Storia Contemporanea, in G.P. Brunetta and C.A. Zotti Minici, La fotografia come fonte di storia, Venice, Ivsla Editor, 2014, pp. 75-94.

8 See V. Piccioni, Un sogno a Roma: la storia di Abebe Bikila, Acsi Campidoglio Palatino, Rome 2003 and the most recent L. Violette, Sport et Politique: the Abebe Bikila symbole: Un athlète éthiopien en 1960, EUE, SL, 2010.
} 
the type of invented archive ${ }^{9}$ could be created. Then each student chose, from the common archive, a group of homogeneous photos; starting from them, the student created a sports almanac, in which each image was read in the light of the economic, historical and political context of the moment. The work was carried out by making short videos uploaded on a YouTube channel, with limited access to course participants only ${ }^{10}$.

\section{FINAL CONSIDERATIONS}

If the initial assumption was to reconcile traditional didactics with new models of media narration, we must acknowledge that the digital model, the internet and the lowering of the electronic devices costs, with their widespread distribution, have taken away the monopoly of the conveyance of the historical narration from the paper, and allow for a change in the methods of research, narration and sharing of History today. This is a soil that historians have initially stepped onto with some uncertainty, but which has given rise to a now incontrovertible process of changing the methods of access to knowledge and even to a new disciplinary area, i.e. that of digital history, which projects the study of history in a context of epistemological and methodological interdisciplinarity ${ }^{11}$. This is one of the possible ways to undertake for the revival of the History of Sport, a discipline that can play a fundamental role in spreading a sports culture and ethics of which, as showed by the upsurge in violence in the stadiums or even the recent homophobic attacks suffered by some members of women's football cubs (to give just a few examples), we feel the need.

Nowadays, the effort of the teacher must be primarily that of enhancing digital instrumentation and media languages, without however giving up conveying not so much contents, but a rigor of method and critical spirit. The students of the course were offered the opportunity to manipulate and manage the narrative of the past by composing a coherent mosaic, in which social history, political history and Sport represented different pieces belonging to the same colour gradient. In the final work, the chosen photographs came to life in the story that interpreted and read the sports performance in the light of what was happening outside the track, the stadium or the sports hall. No longer a work destined to the mere objective of the didactic assessment, but a creative effort that can be enjoyed by many, in which young people were asked to express themselves in a public and open environment, without filters and protections, to demonstrate technical competence and critical and abstraction skills, the acquisition of that knowledge which enables us to follow and respect the ancient ones to which the historian has always conformed when doing his work ${ }^{12}$.

\section{REFERENCES}

Brunetta G.P. e Zotti Minici C. A., La fotografia come fonte di storia, Venezia, Ivsla, 2014.

Colombi V., Greppi C., Manera E., Olmoti G., Roda R., I linguaggi della Contemporaneità. Una didattica digitale per la storia, Bologna, II Mulino, 2018.

Dalola D. e Rabitti M.T., La storia oltre i manuali. Come usare testi storiografici e testi di finzione storica, Milano, Mnamon Editor, 2017.

D’Autilia G., L'indizio e la prova. La storia nella fotografia, Milano, la Nuova Italia Editor, 2001.

\footnotetext{
${ }^{9}$ E. Salvatori, Digital (Public) History: la nuova strada di una antica disciplina, in Rime, 1 (2017), 1, pp. 84-85.

10 With the private circulation of the videos we have tried to avoid incurring any penalties due to the absence of the rights on the images used.

11 G. De Luna, La sfida della rete, in V. Colombi, C. Greppi, E. Manera, G. Olmoti, R. Roda, I linguaggi della Contemporaneità. Una didattica digitale per la storia., Bologna, II Mulino Editor, 2018, pp. 27-35.

12 On laboratory didactics, see also D.Dalola and M.T. Rabitti, La storia oltre i manuali. Come usare testi storiografici e testi di finzione storica, Milan, Mnamon Editor, 2017.
} 
Doris E. e Stagi P.A., Coppi e Bartali. Una storia italiana raccontata ai miei figli, Milano, Solferino Editor, 2019.

Piccioni V., Un sogno a Roma: la storia di Abebe Bikila, Acsi Campidoglio Palatino, Roma 2003.

Salvatori E., Digital (Public) History: la nuova strada di una antica disciplina, in Rime, 1 (2017), 1.

Santarelli N. e Teja A., Chi ha ucciso la storia dell'educazione fisica e dello sport in Italia? in Sport and Violence, Universisad Pablo de Olavide, Cadiz, 2006.

Violette L., Sport et Politique: le symbole Abebe Bikila: Un athlète éthiopien en 1960,EUE, s.l., 2010. 